\title{
Women in household decision-making and implications for dietary quality in Bhutan
}

\author{
Orkhan Sariyev $^{1 *}$ D, Tim K. Loos ${ }^{2}$, Manfred Zeller ${ }^{1}$ and Tulsi Gurung ${ }^{3}$
}

\author{
* Correspondence: o.sariyev@uni- \\ hohenheim.de; orxan.sariyev@gmail. \\ com \\ ${ }^{1}$ Faculty of Agricultural Science, \\ Hans Ruthenberg Institute, \\ University of Hohenheim, \\ Wollgrasweg 43, 70599 Stuttgart, \\ Germany \\ Full list of author information is \\ available at the end of the article
}

\begin{abstract}
Despite the wide range of literature supporting the linkages between women's empowerment and food security, it is not examined in social contexts where females historically enjoy equality and even favoritism, for instance where there is female succession and/or polyandry. This study was done in the Kingdom of Bhutan where matrilineal succession and polyandry were prevalent during the twentieth century. Both quantitative and qualitative survey methods were employed with the objectives of (i) investigating women's participation in crucial domestic decision-making processes and (ii) identifying the implications of female involvement in domestic decision-making on household-level dietary quality.

While descriptive analyses and qualitative interviews revealed that women do not lack significant participation in domestic decision-making, the estimations indicate that the relationship between women's participation in decision-making and dietary diversity is non-linear. Further analyses indicate a positive association between (perfect) gender equal decision-making regarding household livelihoods and household-level dietary quality.

Keywords: Decision-making, Gender equality, Dietary quality, Bhutan
\end{abstract}

\section{Introduction}

Seventeen sustainable development goals have been set to be achieved by 2030 (World Health Organization 2018). Gender equality is one of the cross-cutting issues highlighted in several of these goals. Fostering gender equality will contribute to and enhance the speed of achieving other goals including, for example, zero hunger (Nilsson 2017).

There are numerous studies in the literature showing that women's empowerment is a pathway to sustainable livelihoods. Women are more likely to invest in health and education (Schmidt 2012). Their empowerment has a positive impact on the dietary status of the households (Sraboni et al. 2014). Moreover, gender per se or genderlinked differences in access to resources, in many cases, was found to be a powerful determinant of the adoption of agricultural practices and technologies that increase yield and protect the environment and agro-biodiversity (Doss and Morris 2001; Fisher and Carr 2015; Ndiritu et al. 2014; Ragasa 2012; Simtowe et al. 2016). Kabeer (2001) defines empowerment as an expansion of one's abilities to make crucial life choices.

(c) The Author(s). 2020 Open Access This article is licensed under a Creative Commons Attribution 4.0 International License, which permits use, sharing, adaptation, distribution and reproduction in any medium or format, as long as you give appropriate credit to the original author(s) and the source, provide a link to the Creative Commons licence, and indicate if changes were made. The images or other third party material in this article are included in the article's Creative Commons licence, unless indicated otherwise in a credit line to the material. If material is not included in the article's Creative Commons licence and your intended use is not permitted by statutory regulation or exceeds the permitted use, you will need to obtain permission directly from the copyright holder. To view a copy of this licence, visit http://creativecommons.org/licenses/by/4.0/. 
Obviously, these choices not only affect one's own life but have significant effects at the household and community levels.

Many recent studies present the linkage between women's empowerment and household livelihood outcomes. Programs that contribute to agricultural development will be more effective if they target women. When agricultural income is in women's hands, it is more likely to be spent on health, education, and nutrition. When women have control over assets and decision-making power, they favor agricultural products that support and ensure household food security (Schutter 2013). Sraboni et al. (2014) find a positive association between women's empowerment and dietary diversity as well as calorie availability. However, studies find that male-headed households are more food secure than female-headed households, a finding that can be explained by women's limited access to productive resources (Agidew and Singh 2018; Magaña-Lemus et al. 2016; Tibesigwa and Visser 2016). Although literature about the outcomes of women's empowerment is rich, to the authors' best knowledge, there is no literature about its outcomes in areas where females have historically enjoyed equality, and even in some cases were favored in asset inheritance and experienced polyandry (that is, women take two or more husbands) marriage practices.

This study is done in Bhutan, a country where polyandry was still reported as a prevailing domestic custom in the early years of the twentieth century (Shakespear 2012), and vestiges like fraternal polyandry were still reported in a few nomadic ethnic groups in the early years of twenty-first century (Dorji 2003).

Considering the above-mentioned gap, we aim to contribute to the literature by focusing on one important aspect of empowerment: intra-household decision-making. This study's objectives are (i) to investigate intra-household decision-making and women's participation in crucial decision-making processes of Bhutanese households' livelihoods, and (ii) the outcome of their participation level on the household's dietary diversity that reflects household-level dietary quality. The study adopts the latest methodology introduced by Sariyev et al. (2020) in building an index for women's participation in domestic decision-making and aims to investigate the linkage between dietary quality and empowerment in Bhutanese households.

This paper begins with the background information on the research country (Bhutan) and the status of its female population; it proceeds with a literature review on the linkages between women's status and household food and nutrition security that is followed by a review of tools for measuring empowerment. In the second section, the conceptual framework of the paper is presented. The third section describes the data and methodology employed. The fourth section presents result and discusses them and is followed by concluding remarks in the final section.

\section{Bhutan and the status of women}

The Kingdom of Bhutan is a landlocked South Asian country located in the Himalayas and bordered by India and China. The country remained isolated from the world until the early 1960s. Agriculture has been and remains a dominant sector of the economy. The country is mountainous and widely covered by forests. Except for significant investment in hydroelectric power production, there is little industrial development (Neuhoff et al. 2014). Its population mainly lives in rural areas and depends on agricultural production. 
The remoteness of rural areas is a remarkable challenge for people and their livelihoods. Nonetheless, significant positive improvements were brought by the government's commitment to infrastructural development (Minten and Dukpa 2015). Bhutan's economy is growing fast. In fact, per capita GDP growth remained above 6\% in past few years. It is forecasted that the growth will continue, and Bhutan might become the fastest growing economy in South Asia (Asian Development Bank 2018).

In 2016, the agricultural sector contributed around 17\% to the GDP of the country, and it employed around 58\% of the labor force. Infrastructural development has enhanced the cash crop production of farmers who were mainly subsistence farmers during the twentieth century (National Statistics Bureau 2017). Bhutan has achieved noteworthy progress in the participation of women in the labor force. Nevertheless, much still remains to be improved with regard to the quality of jobs held by women. Moreover, general perceptions in the society about gender roles have moved towards more equality, and women are given off-farm work opportunities, while men increasingly support their wives with child care (World Bank 2013). In rural areas, unemployment rates are higher for women than for men, and in general, the unemployment rate is higher for rural than for urban females. Women constitute a considerable share of educated jobseekers in Bhutan, and they also constitute more of the agricultural labor force than men, and their working hours are longer than men's (Asian Development Bank 2014). Bhutan ranks 110th on the gender inequality index, better than most South Asian countries, especially its culturally and historically close neighbors, India and Nepal. In fact, only the Maldives and Sri Lanka have a better ranking than Bhutan (United Nations Development Program 2018).

FAO (2000) reported that $70 \%$ of the land was owned by women in Bhutan, and matrilineal heritage was seen as the major reason for female favoritism in land inheritance by the end of the twentieth century. World Bank (2013) indicates the matrilineal inheritance practice supports and creates opportunities for Bhutanese women in their empowerment and advancement, and contributes to the gender parity. In 2002, a member of the planning commission reported that in some areas of Bhutan, females controlled around 60\% of property (ThingsAsian 2002). Moreover, Martin Brauen (1997) (as cited in Pain and Pema (2004)) in his study in Bhutan provides clear family examples evidencing matrilineal inheritance and female domination in land ownership and household headship. In Bhutan, according to the Land Act of 1979, men and women have the same rights in land ownership. Moreover, there is no reported gender discrimination in land distribution in Bhutan, unlike in other South Asian countries. In this regard, Agarwal's book "A field of one's own land: Gender and land rights in South Asia" (Agarwal 1994), where Bhutan is neither covered nor appears on the map, highlights the importance of land ownership on women's empowerment. Thus, as also mentioned by Pain and Pema (2004), one would need to carefully search for an answer as to whether Agarwal's argument that ownership has enhanced women's well-being holds true in case of Bhutan. The Asian Development Bank (2014) does not confirm this pattern and reports that Bhutanese culture also enables women to be powerful participants in household decision-making processes. Although, land is an important resource, this does not mean that females are absolutely better off. Rural women have higher illiteracy rates than men, and their access and use of financial resources is limited (World Bank 2013).

While, historically, matrilineal heritage supported daughters in land inheritance, nowadays, it has moved towards more equality. All children regardless of their gender inherit 
lands from their parents mostly in equal shares. It is questionable if historical favoritism of women in land inheritance actually gave them any economic benefits. Despite the favoritism in land inheritance, their decision-making power over land was mostly limited. Men are reported to be the main decision-makers regarding land use. While decisions were generally found to be taken jointly, females were found to be sole decision-makers mostly only in the case of an absent male (World Bank 2013).

\section{Women's status and food and nutrition security}

Although it is widely cited that women produce around 60\% of the world's food, empirically it is impossible to quantify female contribution to the food production as the production process involves both genders, and disaggregation is in most cases not possible. What is important is to highlight that women are principal in food production (Doss 2014) and homestead lands that are mostly used by females contribute a great deal to the dietary diversity of the households (Doss et al. 2018).

Women's status is found to have a significant positive effect on the nutritional status of children in South Asia, Sub-Saharan Africa (SSA), and Latin America. Sariyev et al. (2020) show a positive effect of women's participation in household decision-making on dietary diversity in Ethiopian households. In Malawi, analysis shows that if femaleheaded households enjoy equality in access to productive resources their food security significantly improves (Kassie et al. 2015).

In many parts of South Asia, there are inequalities in distribution of power within families. These inequalities can have different individual level outcomes regarding education, employment, and nutrition. The presence of this intra-household inequality can be observed as females eating left-over food and female children being fed less than male children. This is expressly present in poor households (Mukherjee 2009). Poor households are poor because of their limited productive resources, and it is often observed that food is assigned to higher priority members of the household who are quite often male (Miller 1997). Thus, the status of women may directly affect both their own and their daughters' nutritional status. Malapit et al. (2015) find positive implications for different specifications of female empowerment on dietary diversity of women and children in Nepal. Moreover, in Bangladesh, the status of women is found to be positively linked with long-term nutritional status of children (Bhagowalia et al. 2012).

The large pool of literature on the interaction of food security and gender shows that investing in rural women is a proven method to contribute to household-level food and nutrition security. Among many analyses regarding food security, empowerment and their interaction in South Asia, the authors here fail to find any such studies in Bhutan or in any similar context. The study aims to contribute a good deal to the literature on women's participation in intra-household decision-making.

\section{Measuring empowerment}

Kabeer (2001) finds that empowerment should be seen as a process of expansion in one's freedom to make choices that affect one's life. Its aim is to grant one's deserved control over resources and decisions (Malhotra and Schuler 2005). In this study, we look at the decision aspect. As mentioned, land is a crucial productive resource over which Bhutanese women exercise control and in most cases, even enjoy favoritism. 
Empowerment is difficult to measure as it is not directly observable. In light of this well-known difficulty, Malhotra and Schuler (2005) identify four possible ways of measuring empowerment. One of these approaches measures empowerment through survey questionnaires that capture aspects of one's empowerment. This study uses the same strategy and tries to measure women's empowerment through their participation in decision-making. Women's participation in household decision-making is widely considered a good measure of empowerment (Acharya and Bennett 1983; Allendorf 2007; Bhagowalia et al. 2012; Schuler et al. 1996).

Malhotra and Mather (1997) consider domestic decision-making one of the dimensions of empowerment along with paid work and education. Becker et al. (2006) reported and analyzed decision-making as a measure of empowerment using analysis of husband and wife reports on household decision-making, which revealed differences in the reported participation of wives. As mentioned, this is considered the main shortcoming of this approach of measuring empowerment. Hashemi et al. (1996) and Garikipati (2008), both use decision-making power as a proxy of empowerment along with a few other proxies to investigate the effect of credit programs on women in Bangladesh and India. Another example is from a nation close to Bhutan-Nepal, where empowerment was measured through questions on decision-making power. The analysis concentrates on uncovering the effect of owning land on the decision-making power of women. The results suggest that there is a high probability that women who own land have a final say or at least participate in joint decision-making (Allendorf 2007). This proves our earlier suspicion. A similar effect could be expected in Bhutan as well. To capture the level of female voices heard and preferences declared in domestic decisionmaking, we adopt a recently suggested approach by Sariyev et al. (2020) that enables the consideration of possible participation by all members in decision-making processes and aims to quantify women's participation in them.

\section{Conceptual framework}

The underlying conceptual framework described in Fig. 1 is adapted from Headey et al. (2011). It describes linkages between agriculture and nutrition affected by different socioeconomic factors. One key aspect is intra-household inequality, which is presumed to cause a leakage in the pathway. Agricultural policy at the national level influences the production of food, household income, and the amount spent on food and nonfood purchases. This is followed by its effect on the households' nutritional and health outcomes, which are determinants of individual nutritional intake and healthcare, respectively. Intra-household inequality can cause leakages in the pathway towards better nutrition. Headey et al. (2011) introduce intra-household inequalities that cause leakages with regard to food allocation among household members, and thus individuals' food security. This study extends this approach and aims to discover the relation to the household-level dietary quality, measured by the Food Variety Score (FVS) and the Household Dietary Diversity Score (HDDS). An increase in female participation in decision-making in households where inequality exists and males enjoy much stronger decision-making power than females is expected to positively contribute to the linkage.

In general, gender inequality is a cross-cutting issue that needs to be considered if good nutritional attainments are to be achieved (Headey et al. 2011). Emphasizing that this 


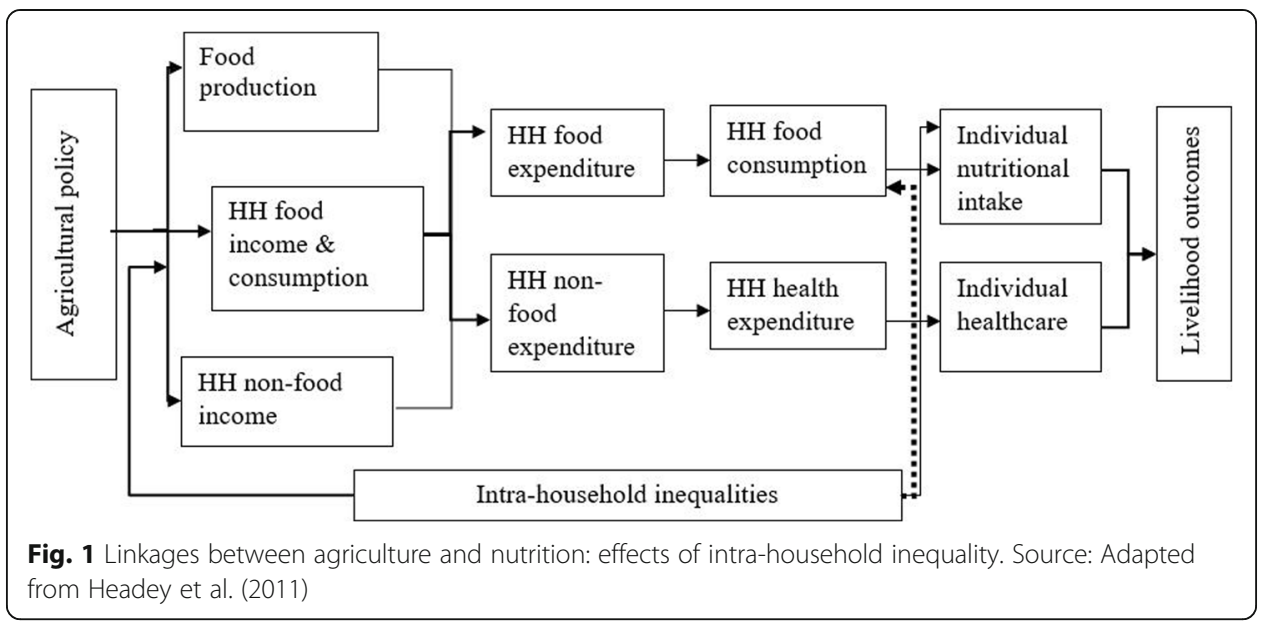

study investigates intra-household decision processes of Bhutanese households and aims to identify the effect of women's participation level in domestic decision-making on the Bhutanese household nutritional outcomes, the study will test the following hypotheses:

H I.Considering historical matrilineal heritage in Bhutan, women are not expected to be significantly lacking in participation in domestic decision-making.

$\mathrm{H}$ ITThe level of women's participation in household decision-making determines the level of dietary diversity in the households. Echoing the thoughts of Headey et al. (2011), an increase in participation in decision-making will be associated with better outcomes in low levels of gender equality, but negative outcomes if it leads to inequality or one gender's dictatorship in decision-making. Thus, the association between women's intra-household decision-making power and household-level dietary quality is expected to be nonlinear.

\section{Methods}

\section{Data}

The data analyzed in this study were collected in November 2017 and cover 251 households in two central western Dzongkhags (districts) of Bhutan: Tsirang and Dagana. It needs to be noted that because of time and financial constraints, this study was done in two central western regions of Bhutan with better road infrastructure than the north of the country. Multistage sampling was used. Simple random sampling was employed in all stages. In each of the seven randomly selected Gewogs (wards), three Chiwogs (villages) were randomly selected. Using the household lists acquired from the administration office, 12 randomly selected households were interviewed in each Chiwog. The survey was conducted by trained enumerators with a very good command of the local languages of the survey area. In order to secure data quality during data collection, computer-assisted personal interviewing (CAPI) devices were carried. The questionnaire covered 10 sections that were related to household socio-economic characteristics, infrastructural situations, social networks, extension, household assets, land endowment, crop production, livestock production, labor and seasonality, food consumption, and expenditure. Farmers were asked questions regarding domestic decision- 
making in all areas where households make crucial decisions that affect their livelihoods.

Moreover, qualitative in-depth interviews were conducted in randomly selected households in both Dzongkhags. These enabled us to freely discuss, understand, and capture different perceptions in the intra-household decision-making of Bhutanese households and served as complementary information to the quantitative survey.

Although the minimum legal age of marriage, which one could regard as the formation of a new household, is 18 (Tahirih Justice Center 2014), UNICEF (2013) reports marriage at the age of 15 for $6.2 \%$ of the married population. Thus, the age eligibility criterion for consideration as a potential participant in domestic decision-making is 15 years. Members younger than 15 were not considered potential participants of decision-making processes. During the in-depth interviews, this cut-off point proved practically valid and was expressed distinctly by a farmer in Tsirang Dzongkhag who had two sons and a daughter:

For smaller things no need to give the headache. I want my children to feel considered, or they might think we don't care about their ideas. Class 10 is the time when they became an adult, that is when they are around 15-16 years old. When they are younger, their attention is to the school, no need to discuss with them anything, that is just an additional headache then.

and he added, "My kids studied until class 10, after, they decided to quit, and it was already their decision."

This farmer reported that the decision was mostly taken by him and his wife, and children were also consulted in a few cases. Moreover, another farmer in Tsirang Dzongkhag on a question regarding children and their age to be eligible to participate in decision-making replied, laughing, "I was 14 years old when I got married, that was already a big decision," and added, "I also consult my son, because later this land will be his land. I must discuss it with him."

Thus, in light of different perspectives regarding children and their eligibility to participate in decision-making, this study determines and concentrates on individuals who are 15 and older in the analysis of decision-making as the early marriage age and in-depth interviews signal that the age specification should be between 14 and 16 years old.

Although the full sample contains 251 households, the analysis concentrates on 213 households as the rest of the households do not contain either male or female adult members within the appropriate age range, and thus we are unable to capture any potential gender bargaining in decision-making in those 38 households. This high dropout rate can be explained by the social situation in Bhutan where one can find many households with only one gender present, for example, where couples live separately or where a family member is employed and lives in an urban area.

\section{Methodology}

In interviews regarding domestic decision-making processes, household heads were first given a choice of reporting if the decision had been made by one household member, jointly by two household members, jointly by all household members or by someone outside the household. The names and household member IDs of the decision-makers in options of one household member and two household members were inserted by 
enumerators into the CAPIs. This enables the identification of the sex of decisionmakers by way of cross-link to the household roster in CAPIs. Overall, as suggested by Sariyev et al. (2020), the decision made is considered a unit outcome in the analysis. To identify women's participation levels in the decisions, this study adopts this approach and uses the following formula:

$$
W P D M_{i}=\frac{\sum F P D M_{i}}{\sum P D M_{i}}
$$

where WPDM stands for women's participation in decision-making and FPDM and PDM represent female participant and any gender participant in decision-making processes, respectively, in the $i$ th domain. Thus, the number of female participants is divided by the total number of participants in decision-making which leads to WPDM ranging from 0 (no female participation) to 1 (full control over decision-making by females).

Households must make various decisions to devise their livelihoods. This study investigates all potential decision-making processes that households hold. Naturally, households have different socio-economic characteristics and participate in different and various activities that might not be consistent among all households. That is why, in measuring women's participation in domestic decision-making, the analyses are limited to the most important aspects of household livelihoods that is the decisions observed to be taken by almost all sample households in Bhutan. In this regard, the analyses consider decision-making processes regarding (i) household asset purchases, (ii) food purchases, (iii) crops grown, (iv) harvest use, (v) use of income from crop, (vi) input use, and (vii) land use. Variables of these seven decision-making processes (their respective WPDMs) are generated, and weights are assigned based on Formula 1. This is followed by a principal component analysis (PCA) to transform this set of correlated decisionmaking variables into one index: women's participation in domestic decision-making or intra-household decision-making (WPDMI). The terms "domestic" and "intra-household" are used interchangeably.

Further, we investigate WPDM variables to understand the intra-household decisionmaking in Bhutanese households. Moreover, to test H I, non-parametric statistical analyses are employed between three land ownership groups: male, female, and jointly owned. We define the land ownership variable as the ownership status of the largest parcel that household owns.

Regarding the second objective of this study, WPDMI is regressed against two dietary diversity indicators: FVS and HDDS. Both are calculated using the reported domestic food consumption in the 7 days before the interview. Here, FVS is a simple count of different food items consumed by household members (Hatløy et al. 1998). Following guidelines by Kennedy et al. (2011), food items are aggregated into 12 food groups. HDDS is a simple count of households' consumption of food items from aggregated food groups. Obscure cut-off point in the number of food groups consumed to determine nutritional adequacy and minimum required size of serving for consideration in a food group are the main critics of dietary diversity scores. Dietary diversity indicators are not comprehensive food security measures (Cafiero et al. 2014). Nevertheless, household-level dietary diversity is found to be a good measure of household food access in multi-country level analysis (Hoddinott and Yohannes 2002), and its strong association with household-level per capita energy availability makes it an appropriate 
food security indicator for this study (Ruel 2003). Moreover, Headey and Ecker (2013) mention that dietary diversity indicators perform better than other food security indicators across various food security criteria. Individual dietary diversity is observed to increase the probability of nutrient adequacy (Foote et al. 2004; Hatløy et al. 1998; Steyn et al. 2006). Considering that individual and household dietary diversities are correlated (Fongar et al. 2019; Koppmair et al. 2016), we assume dietary diversity indicators are good measures of household-level dietary quality. Hatløy et al. (1998) find that the association of HDDS with nutrient adequacy is stronger than that of FVS. Although HDDS is simpler to collect during field surveys than FVS, we employed both measures for robust estimates. Following Ruel's (2003) recommendations for the recall period, we used the 7-day recall as it is the longest reference period with the least recall error.

Dietary diversity indicators are regressed against WPDMI in linear regression models (2) and (3) to discover the linkage between women's participation in decision-making and household-level dietary quality. Moreover, consistent with H II, non-linear models in (4) and (5) were checked against the hypothesis that the interaction is linear.

$$
\begin{aligned}
& F V S_{\mathrm{i}}=\beta_{0}+\beta_{1} W P D M I+\beta_{2} X+u_{i} \\
& \operatorname{HDDS}_{i}=\beta_{0}+\beta_{1} W P D M I+\beta_{2} X+u_{i} \\
& F V S_{1}=\beta_{0}+\beta_{1} W P D M I+\beta_{2} X+\beta_{3} W P D M I^{2}+\beta_{4} W P D M I^{3} \cdots+\beta_{r} W P D M I^{r}+u_{i} \\
& H_{D D S}=\beta_{0}+\beta_{1} W P D M I+\beta_{2} X+\beta_{3} W^{2} P D I^{2}+\beta_{4} W P D M I^{3} \cdots+\beta_{r} W P D M I^{r}+u_{i}
\end{aligned}
$$

where $X$ (a control variable), $r$ (the degree of polynomial that needs to be identified in the analyses), and $u_{\mathrm{i}}$ (the residual term's normal distribution) are assumed based on the central limit theorem.

\section{Results}

This section begins with a statistical description of sample households then with regard to objective (i) and H I, women's participation in different household-level decisionmaking processes is investigated. Then, regarding objective (ii) and H II, econometric estimations of the association between women's participation in domestic decisionmaking on two dietary quality indicators (FVS and HDDS) are presented and discussed.

\section{Descriptive analyses}

Table 1 presents descriptive statistics of the sample population. Of the sampled households, $69 \%$ are headed by males, and the average age of heads is 52 . Households have on average around three members and a dependency ratio of 0.17 . Here, dependency ratio captures the share of dependents who are below 15 years of age or above 64 in the household. On average, households are $10 \mathrm{~min}$ away from their parcels that they have reported to have an average soil quality of a little above moderate. The average farm size is 3.92 acres. Households plant on average three to four different crops and have two types of livestock on their farms. Over the year, on average, an income of almost $77,900 \mathrm{BTN}^{1}$ is earned from on-farm activities by sample households who are on

${ }^{1}$ Bhutanese ngultrum. USD $1=$ BTN 65.40 and EUR $1=$ BTN 77.25 at the time of the survey Deutsche Bundesbank (2018). 
Table 1 Descriptive statistics of the sample households

\begin{tabular}{lll}
\hline Variables & Mean & SD \\
\hline Household head sex [0 = female, 1 = male] & 0.69 & 0.46 \\
Household head age [years] & 52.48 & 14.34 \\
Household size & 3.46 & 1.30 \\
Dependency ratio & 0.17 & 0.20 \\
Farm size [acres] & 3.92 & 2.89 \\
Average distance to the parcels [minutes] & 10.20 & 15.94 \\
Soil quality [1, very poor-5, very good] & 3.48 & 0.59 \\
Crop diversity [\# of different crops produced] & 3.44 & 1.44 \\
Livestock diversity [\# of different animals owned] & 2.18 & 1.53 \\
Total agricultural income [BTN] & $77,867.67$ & $277,429.4$ \\
Distance from farm road [min] & 7.83 & 10.59 \\
HDDS & 8.74 & 2.04 \\
FVS & 15.24 & 5.58 \\
WPDM regarding household asset purchases & 0.44 & 0.22 \\
WPDM regarding agricultural asset purchases & 0.41 & 0.29 \\
WPDM regarding animal purchases, sales, and inputs & 0.44 & 0.24 \\
WPDM regarding crop grown & 0.52 & 0.21 \\
WPDM regarding food purchases & 0.52 & 0.29 \\
WPDM regarding harvest use decisions & 0.51 & 0.20 \\
WPDM regarding animal income use & 0.44 & 0.24 \\
WPDM regarding the use of income from crop & 0.51 & 0.20 \\
WPDM regarding input use for crop & 0.48 \\
WPDM regarding land use & 0.47 \\
\hline SOure: Authors data & & 0.25 \\
\hline
\end{tabular}

Source: Authors' data

average 8 min away from farm roads. In the sample households, FVS ranges from 3 to 29, and HDDS ranges from 3 to 12. Mean HDDS and FVS of the sample households are 8.7 and 15.2, respectively. This gives the impression that good dietary diversity exists in the sampled Bhutanese households.

Looking at the descriptive statistics regarding women's participation levels in different aspects of domestic decision-making shown in Table 1, it becomes clear that females do not fully lack participation. They are involved in 40 to $50 \%$ of decision-making, which approaches equality in participation. In a few decision-making areas, like crops grown, food purchases, harvest use, and use of income generated from crop production, females' thoughts even enjoy a little more consideration than males'. Whereas, on average, males' preferences are considered more in decision-domains like animal purchases and sales, use of income from animals, land use, and household and agricultural asset purchases. Interestingly, it becomes apparent that on average females' voices are more heard in decisions regarding crop production than males', while males' voices are stronger in decisions regarding animal production. Besides, it is observed that decision-making processes regarding agricultural asset purchases account for more male participation than any other domestic decision-making fields, while female voices are stronger in food purchases.

Figure 2 highlights the distributions with regards to the different decision-making domains of WPDM variables. WPDM variables range from 0 to 1 where 0 and 1 imply sole 


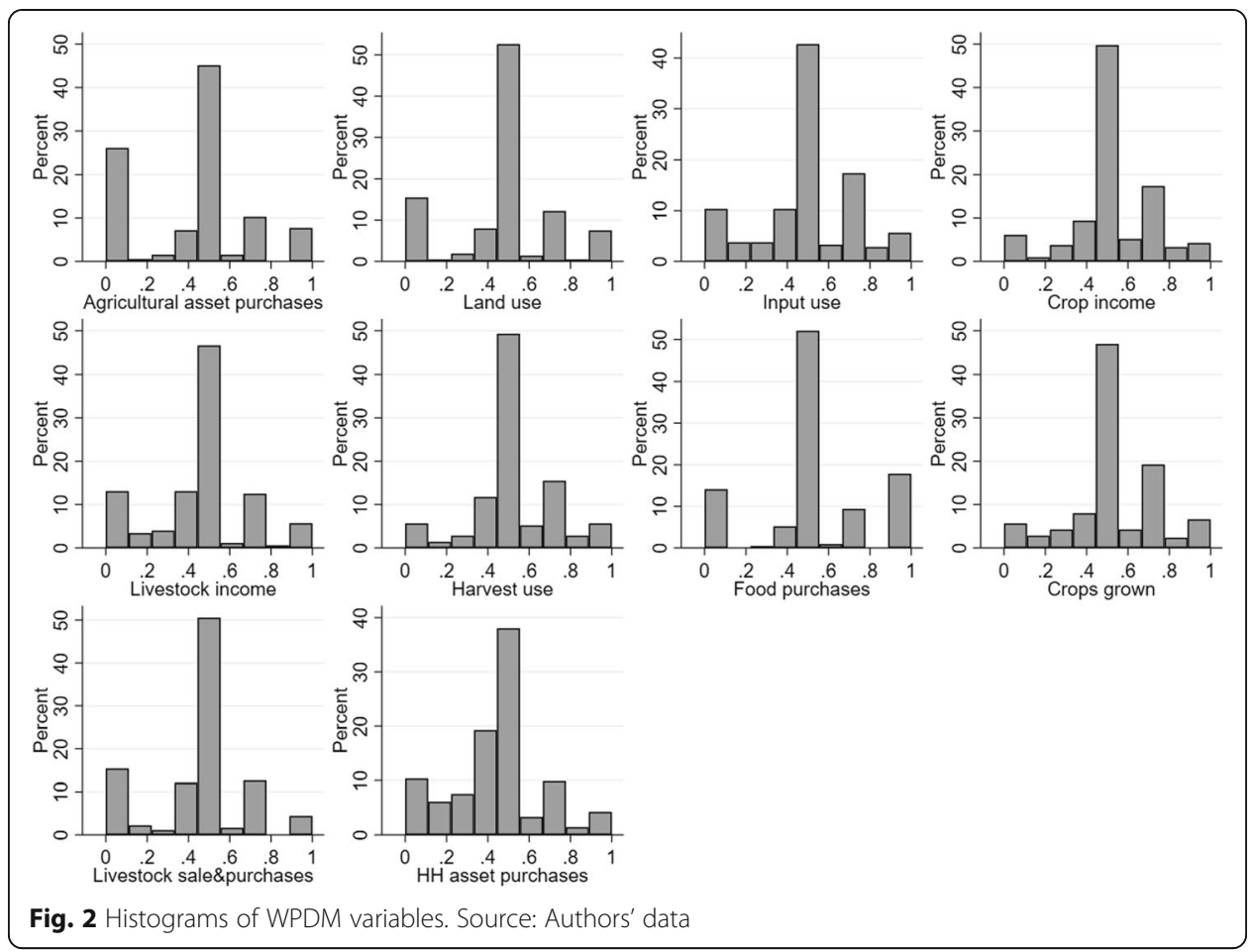

decision-making. A score of 0.5 indicates perfect gender equality in decision-making. Here, it becomes more detectable that most of the observations fall around 0.5, indicating high levels of gender equal decision-making in Bhutanese sample households. Again, it is evident that decision-making regarding agricultural asset purchases seems to be dominated by males in one-quarter of the sample households.

In-depth interviews were conducted with households from different ethnic and social backgrounds. Overall, in most of the households, we observe that females do not lag behind in terms of participation in decision-making regarding crucial aspects of household livelihoods. It is worthwhile to mention that in families of Nepalese origin, males were observed to be dominant (sole) in decision-making. We would also like to highlight our observation during the in-depth interviews that females seemed very interested and wanted to hear and contribute to the interview when the head is male, and in a unique household, the man declared that his wife knows all the details, and we should be talking to her if we are to ask about household livelihoods.

\section{Land ownership and participation in domestic decision-making}

In order to account for the presence of historical matrilineal succession in Bhutan, the analyses look at WPDM in three different land ownership scenarios: male, female, and joint ownership. Land ownership is captured on the largest parcel that the household owns. In 27 and 39 households, females and males own the largest parcel in the household, respectively. Thus, the remaining 142 households fall into the joint ownership category. A non-parametric Wilcoxon rank-sum test (Wilcoxon 1945) was conducted between groups of land ownership types to find out if statistical differences exist. Table A1 of the "Additional file" section presents a pairwise comparison of WPDM in the three 
situations throughout seven household decision-making domains. Further analyses will be limited to the decision-making domains that are observed in almost all sample households: (i) asset purchases, (ii) food purchases, (iii) crops grown, (iv) harvest use, (v) income use, (vi) input use, and (vii) land use. In the sample households, results of the tests suggest that in almost all seven fields of decision-making, WPDM's distribution is statistically different for all three land ownership groups. Overall, regarding the WPDM, households in the female lands category rank higher than expected in contrast to households in the male and jointly owned land categories. For a better understanding, we look into the probabilities of each group having a greater WPDM than others in Table 2. WPDM is expected to be greater in households where a female owns the largest parcel than in households where a male owns the largest parcel with highest probability of $87 \%$ observed in decision-making regarding land use. The second column compares the WPDM of households in the female ownership category with those in the joint ownership category. Here, the highest probability (79\%) is observed in decisions regarding land use, and the lowest probability (54\%) is in the decisions regarding asset purchases. Moreover, a comparison of male and joint ownership groups in the third rows shows that the probability of WPDM being higher in male owned lands than jointly owned lands is generally low, with the lowest probability in decisionmaking regarding asset purchases (15\%) and the highest regarding crops grown (37\%).

Additionally, in-depth interviews did not reveal any significantly observable gender difference in land inheritance. In most cases, household heads declared that they will divide the land equally between their children and added that this has something to do with the government's advocacy regarding gender equality. It is necessary to highlight a section from an interview with a female who was living with her husband in her father's house during the survey in Dagana Dzongkhag:

In my family, after we make a decision with my husband, we still report and discuss it with my dad. In the future, when it is just me and my husband, I would be the main decision-maker, since I will have the land inherited from my parents. It is even me now who is much stronger.

Altogether, regarding objective (i) of this study, the descriptive analyses of women's participation in domestic decision-making in sample Bhutanese households suggest that women do not lack any significant participation. This is consistent with H I. This was

Table 2 Estimated probabilities of greater WPDM between land ownership groups

\begin{tabular}{llll}
\hline $\begin{array}{l}\text { Domestic } \\
\text { decision- } \\
\begin{array}{l}\text { making } \\
\text { regarding }\end{array}\end{array}$ & $\begin{array}{l}\text { WPDM in... } \\
\text { Female owned }>\text { male }\end{array}$ & $\begin{array}{l}\text { Female owned }>\text { jointly } \\
\text { owned }\end{array}$ & $\begin{array}{l}\text { Male owned }>\text { jointly } \\
\text { owned }\end{array}$ \\
\hline $\begin{array}{l}\text { Asset } \\
\text { purchases }\end{array}$ & 0.78 & 0.54 & 0.15 \\
Food purchases & 0.78 & 0.67 & 0.27 \\
Land use & 0.87 & 0.79 & 0.27 \\
Crops grown & 0.77 & 0.72 & 0.37 \\
Input use & 0.77 & 0.62 & 0.28 \\
Income use & 0.74 & 0.63 & 0.35 \\
Harvest use & 0.78 & 0.69 & 0.35 \\
\hline
\end{tabular}


also widely observed during qualitative interviews. In a few exceptional cases, males had sole decision-making power and, in these cases, we were able to observe a limited socio-economic status of female members in the household. The reason was explained by a 57 -year-old lady:

I am not educated, and I do not feel confident... I think my husband knows best as he is educated. I would not risk trying to change his decision.

This supports the well-known positive effect of education on empowerment. Moreover, the matrilineal succession practice may have contributed to women's empowerment over time as we observe a positive association with women's property rights over land and participation in decision-making.

\section{WPDMI and dietary quality}

By means of PCA, seven WPDM variables are used to generate the WPDMI. In order to address the second objective and test $\mathrm{H}$ II, the index is used as an explanatory variable, and its effects on HDDS and FVS are estimated.

The WPDM variables show a significantly strong pairwise correlation, as presented in Table A2 of the "Additional file" section, which is a prerequisite of PCA. The factor analyses yield only one factor with an eigenvalue above 1 (4.5295), which captures 65\% variation in the WPDM variables. This captured information is believed to be the participation in decision-making. We retain only this factor in the analyses according to the Kaiser criterion (Kaiser 1960). Table 3 presents factor loadings and Kaiser-Meyer-Olkin (KMO) values of WPDM variables. All variables yield factor loadings of greater than 0.4, and KMO results are great $(>0.8)$ for four variables and superb $(>0.9)$ for the rest of the variables. These results indicate that the factors are reliable, and predicted index, WPDMI is representative of the common information shared by WPDM variables (Kaiser 1974).

WPDMI is used to investigate the association between women's participation level in domestic decision-making and dietary diversity of the households. FVS and HDDS are regressed on WPDMI and other explanatory variables. Regressions results are reported in Table 4. H II is tested by employing polynomials of WPDMI. First, exploring the coefficients of other independent variables, we find a robust negative association between the dependency ratio and household dietary diversity in all employed models. Soil

Table 3 Factor loadings and KMO values of WPDM variables

\begin{tabular}{lll}
\hline WPDM regarding... & Factor loading & KMO \\
\hline Asset purchases & 0.6660 & 0.8711 \\
Crops grown & 0.9124 & 0.8311 \\
Food purchases & 0.5413 & 0.8714 \\
Harvest use & 0.9155 & 0.8078 \\
Income use & 0.8148 & 0.9422 \\
Input use & 0.9079 & 0.9319 \\
Land use & 0.7962 & 0.9431 \\
Eigenvalue & & \\
$\mathrm{KMO}_{\text {overall }}$ & & \\
\hline
\end{tabular}

Source: Authors' estimation 
Table 4 Linear, quadratic, and cubic estimations of WPDMI on FVS and HDDS

\begin{tabular}{|c|c|c|c|c|c|c|}
\hline \multirow[b]{2}{*}{ Variables } & \multicolumn{3}{|l|}{ FVS } & \multicolumn{3}{|l|}{ HDDS } \\
\hline & Linear & Quadratic & Cubic & Cubic & Quadratic & Cubic \\
\hline \multirow[t]{2}{*}{ WPDMI } & $-0.783^{* *}$ & $-0.853^{* * *}$ & $-1.538^{* * *}$ & $-0.296^{* *}$ & $-0.318^{* * *}$ & $-0.423^{* *}$ \\
\hline & $(0.349)$ & $(0.303)$ & $(0.587)$ & $(0.117)$ & $(0.104)$ & $(0.199)$ \\
\hline \multirow[t]{2}{*}{ WPDMI ${ }^{2}$} & & $-0.622^{* * *}$ & $-0.645^{* * *}$ & & $-0.191^{* * *}$ & $-0.195^{* * *}$ \\
\hline & & $(0.162)$ & $(0.159)$ & & $(0.063)$ & $(0.063)$ \\
\hline \multirow[t]{2}{*}{ WPDMI $^{3}$} & & & $0.165^{*}$ & & & 0.025 \\
\hline & & & $(0.092)$ & & & $(0.036)$ \\
\hline \multirow[t]{2}{*}{ Head age [years] } & -0.031 & -0.022 & -0.023 & -0.010 & -0.007 & -0.007 \\
\hline & $(0.025)$ & $(0.026)$ & $(0.026)$ & $(0.009)$ & $(0.009)$ & $(0.009)$ \\
\hline \multirow[t]{2}{*}{ Member with highest education [years] } & 0.070 & 0.061 & 0.059 & 0.019 & 0.016 & 0.016 \\
\hline & $(0.081)$ & $(0.077)$ & $(0.077)$ & $(0.029)$ & $(0.028)$ & $(0.028)$ \\
\hline \multirow[t]{2}{*}{ Household size } & 0.435 & 0.462 & 0.446 & 0.127 & 0.135 & 0.133 \\
\hline & $(0.311)$ & $(0.308)$ & $(0.311)$ & $(0.105)$ & $(0.106)$ & $(0.106)$ \\
\hline \multirow[t]{2}{*}{ Dependency ratio } & $-3.424^{*}$ & $-2.927^{*}$ & $-2.955^{*}$ & $-1.453^{* *}$ & $-1.301^{*}$ & $-1.305^{*}$ \\
\hline & $(1.806)$ & $(1.740)$ & $(1.734)$ & $(0.708)$ & $(0.682)$ & $(0.684)$ \\
\hline \multirow[t]{2}{*}{ Farm size [log] } & -0.535 & -0.383 & -0.390 & -0.160 & -0.113 & -0.114 \\
\hline & $(0.436)$ & $(0.430)$ & $(0.434)$ & $(0.123)$ & $(0.124)$ & $(0.125)$ \\
\hline \multirow[t]{2}{*}{ Production diversity } & $0.306^{*}$ & 0.258 & 0.232 & $0.199^{* * *}$ & $0.184^{* * *}$ & $0.180^{* * *}$ \\
\hline & $(0.171)$ & $(0.164)$ & $(0.162)$ & $(0.058)$ & $(0.056)$ & $(0.057)$ \\
\hline \multirow[t]{2}{*}{ Distance to the nearest farm road [min] } & $-0.060^{* *}$ & $-0.051^{* *}$ & $-0.050^{* *}$ & -0.014 & -0.011 & -0.011 \\
\hline & $(0.024)$ & $(0.024)$ & $(0.023)$ & $(0.010)$ & $(0.009)$ & $(0.009)$ \\
\hline \multirow[t]{2}{*}{ Soil quality } & $2.343^{* * *}$ & $2.524^{* * *}$ & $2.540^{* * *}$ & 0.345 & $0.401^{* *}$ & $0.403^{* *}$ \\
\hline & $(0.570)$ & $(0.552)$ & $(0.552)$ & $(0.210)$ & (0.199) & $(0.199)$ \\
\hline Observations & 213 & 213 & 213 & 213 & 213 & 213 \\
\hline Adjusted $R$ squared & 0.217 & 0.250 & 0.253 & 0.364 & 0.387 & 0.385 \\
\hline
\end{tabular}

Estimations include location dummies to control for Gewog level characteristics; robust standard errors in parentheses ${ }^{* * *} p<0.01,{ }^{* *} p<0.05,{ }^{*} p<0.1$

Source: Authors' estimation

quality has a positive association in almost all models to both FVS and HDDS. Diversity in agricultural production (that is, simple count of crop and livestock types produced over 12 months) is strongly associated with the higher HDDS, and distance to the farm road is found to be negatively associated with the FVS.

Coming back to the main independent variable of interest, regression results suggest that cubic and quadratic regression models are better fits in estimating the effect of WPDMI on FVS and HDDS, respectively. This means that the interactions between WPDMI and dietary diversity indicators are nonlinear, as hypothesized. This provokes further exploration as to whether this means that moving further from gender equality towards inequality in either direction is negatively associated with dietary diversity of households. In this regard, Fig. 3 depicts the predicted cubic regression line with the scatterplot of FVS and HDDS data holding other independent variables at their sample averages. It is apparent that an increase in WPDMI is associated with an increase in both FVS and HDDS in low levels of WPDMI, while after some threshold level the association is negative. For FVS, there is a point where the decline is substituted with a somewhat constant effect in very high levels of WPDMI. Consistent with the second 


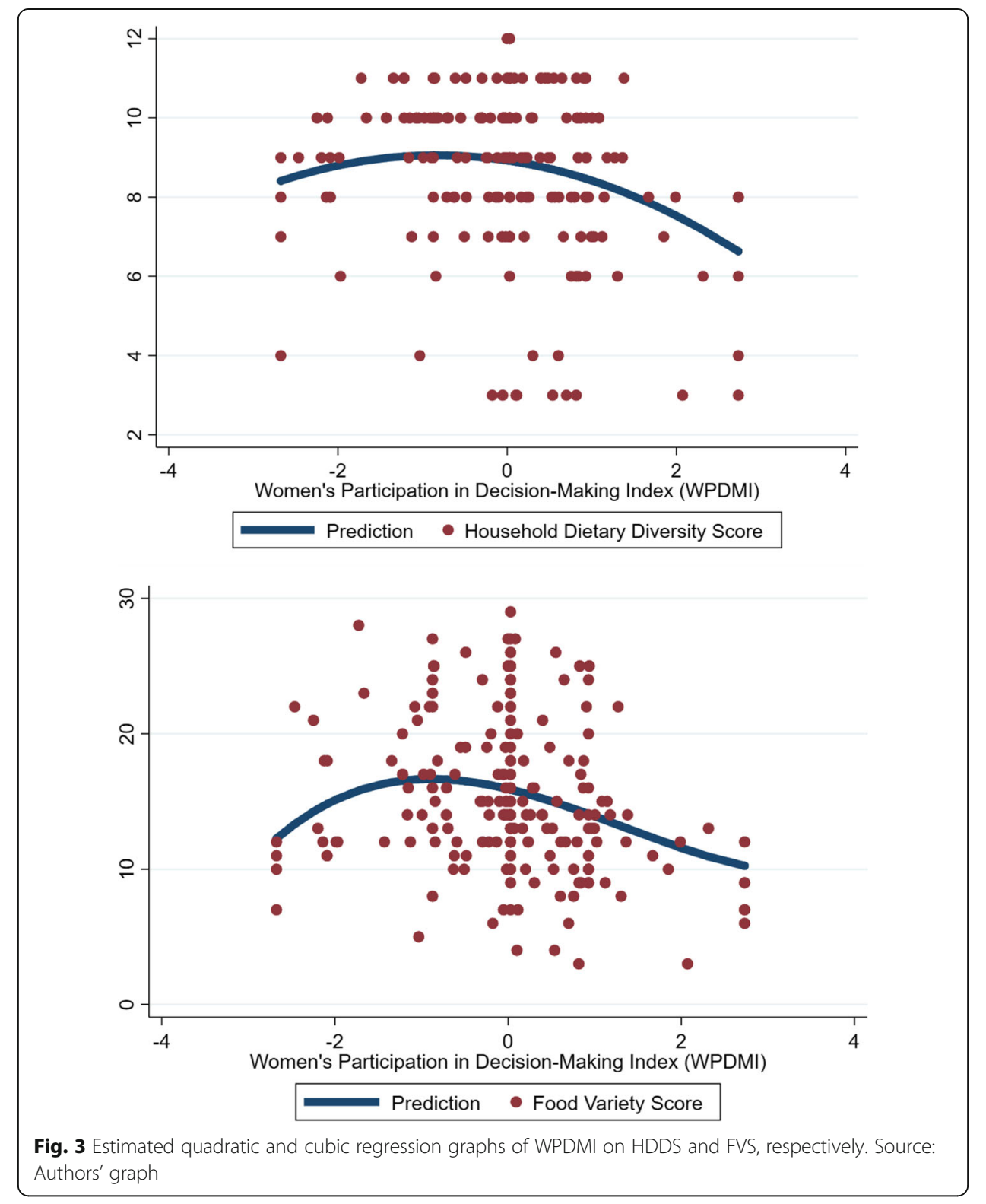

hypothesis of this study, here, the question of interest is whether the initial threshold point is perfect gender equality. Unfortunately, the nature of the participation in the decision-making index generated by PCA does not allow for any such judgement to be made.

Therefore, we transform the original WPDM variables into variables reflecting the level of gender equality in decision-making (GED). As 0.5 in WPDM variables indicates perfect gender equality in decision-making, any movement away from 0.5 must be seen as movement towards inequality. This is captured using the following formula (6):

$$
\mathrm{GED}_{i}=1-\frac{\left|\mathrm{WPDM}_{i}-0.5\right|}{0.5}
$$

GED variables have values ranging between 0 and 1 , representing perfect gender equality and perfect inequality in decision-making, respectively. In the next step, PCA 
is applied to bundle these highly correlated GED variables in an index referred to as the gender equality in domestic decision-making index (GEDI). Table A3 of the "Additional file" section shows PCA results that indicate the index is representative of the common information shared by GED variables.

We employ a linear regression to capture the association between GEDI and household dietary diversity indicators. The results are reported in Table 5. The main independent variable of interest, GEDI is found to be significantly positively associated with both FVS and HDDS. This result suggests that movement in any direction from perfect gender equality in decision-making will result in negative outcomes regarding the Bhutanese households' nutritional status. Moreover, production diversity, which is an unweighted count of crop and livestock units, shows a positive association with HDDS but not with FVS. It is observed that the significance of the association is different for dietary diversity indicators. Similar findings can be observed in meta-analysis by Sibhatu and Qaim (2018). The distance to the nearest farm road is negatively associated with household FVS. Access to the farm road captures households' market access, which is an important determinant of dietary diversity (Sibhatu and Qaim 2018). Increase in household size is associated with better dietary diversity. Additionally, keeping household size and other variables constant, an increase in the dependency ratio associates with lower HDDS. Households size and age structure are human capital indicators of welfare (Henry et al. 2003). A negative association between dependency ratio and HDDS can be explained by the decrease in the household labor force that translates into a loss in overall wealth and thus, access to a varied diet.

\section{Discussion}

The linkage between women's empowerment and food and nutrition security is widely supported by the literature but lacks robustness checks in societies where females historically enjoyed equality or even favoritism in cases like property inheritance, as in Bhutan. Therefore, the first objective of this study was to investigate one aspect of empowerment: women's participation in domestic decision-making. The second objective

Table 5 Linear estimation of association between gender equality in decision-making and dietary diversity indicators

\begin{tabular}{|c|c|c|c|c|}
\hline \multirow[b]{2}{*}{ Variables } & \multicolumn{2}{|l|}{ FVS } & \multicolumn{2}{|l|}{ HDDS } \\
\hline & Coefficient & Robust SE & Coefficient & Robust SE \\
\hline GEDI & $1.326^{* * *}$ & 0.355 & $0.411^{* * *}$ & 0.125 \\
\hline Head age [years] & -0.013 & 0.026 & -0.004 & 0.009 \\
\hline Member with highest education [years] & 0.044 & 0.076 & 0.010 & 0.028 \\
\hline Household size & $0.676^{* *}$ & 0.310 & $0.206^{*}$ & 0.107 \\
\hline Dependency ratio & -2.417 & 1.791 & $-1.124^{*}$ & 0.669 \\
\hline Farm size [log] & -0.251 & 0.422 & -0.067 & 0.123 \\
\hline Production diversity & 0.212 & 0.159 & $0.168^{* * *}$ & 0.055 \\
\hline Distance to the nearest farm road [min] & $-0.045^{*}$ & 0.026 & -0.009 & 0.011 \\
\hline Soil quality & $2.679^{* * *}$ & 0.543 & $0.462^{* *}$ & 0.197 \\
\hline Observations & 213 & & 213 & \\
\hline Adjusted $R$ squared & 0.249 & & 0.381 & \\
\hline
\end{tabular}

Estimations include location dummies to control for Gewog level characteristics. Source: Authors' estimation ${ }^{* * *} p<0.01,{ }^{* *} p<0.05,{ }^{*} p<0.1$ 
was to investigate the association between their participation in domestic decisionmaking and household-level dietary quality.

Historically, women enjoyed favoritism in land inheritance and experienced polyandry in Bhutan. Nowadays, in comparison with other countries in the region, Bhutanese women are found to be better off in terms of equality in many fields of social and household life. This study concentrated on and measured women's participation in different fields of domestic decision-making. Descriptive analyses were conducted to understand the present situation of women. An index was created to quantify their overall participation in domestic decision-making and investigate the association with household-level dietary diversity.

We found that, on average, females have a higher participation rate in a number of decision-making domains. Of the sample households, 45 to $50 \%$ declared proximity to gender equality in decision-making regarding different fields of domestic decisionmaking. Non-parametric test results show that women's participation levels in decision-making is significantly different in different land ownership scenarios. Overall, the probability of women participating in decision-making processes is higher in households where a female owns the largest parcel. This is also the case, when comparing jointly owned lands with male owned lands. We observe an association between land ownership and women's empowerment within households. Overall, we do not find that Bhutanese women lack any significant participation in domestic decision-making. Furthermore, we find positive association between gender equal decision-making and dietary diversity indicators.

Our results are limited in its ability to assess causality between gender equality and dietary quality, and to rigorously investigate the impact of land succession on women's empowerment. Future research could investigate the impact of matrilineal succession practice on women's status more rigorously using a country-level representative longterm panel data, and causality between equality and dietary quality can be addressed employing tools like matching estimators or instrumental variable approach.

\section{Conclusion}

The results lead to two policy implications. Initial analysis in which we employ linear, quadratic, and cubic estimations of the association between WPDMI and dietary diversity measures find that, as hypothesized, the linkage between women's participation in decision-making and dietary quality is nonlinear. Results revealed that women's participation in decision-making is initially associated with positive outcomes. At some point, the association is reversed; a further increase in participation level is then negatively associated with the dietary quality indicators. Thus, women's over-empowerment can distort the objectives of social programs and result in significant negative returns. Social programs that support women's empowerment and nutrition need extensive knowledge of the societies and cultures in which they operate to ensure the effectiveness of their interventions. Therefore, we recommend undertaking ex-ante qualitative research in these types of social programs. Moreover, future research should elaborate on the negative returns of over-empowerment.

To address the second hypothesis and further investigate the nonlinear association between women's participation in decision-making and dietary quality, we generated an index capturing gender equality in decision-making (GEDI). Dietary diversity indicators 
were regressed on GEDI. The results suggest that an increase in intra-household equality in decision-making is positively associated with household FVS and HDDS. The results imply that in social programs, the focus should be on achieving intra-household equality, and not merely on empowering women. Considering that current literature mostly focuses on implications of women's empowerment rather than equality, our findings contribute to the gender literature and highlight the importance of gender equality together with the need to empower women in discriminative societies. Overall, the results confirm the fifth sustainable development goal of the United Nations that is to achieve gender equality.

\section{Supplementary information}

Supplementary information accompanies this paper at https://doi.org/10.1186/s40100-020-00158-0 .

Additional file 1: Table A1. Comparison of WPDM between land ownership types (that is, male, female, and jointly owned lands) Table A2. Pairwise correlation of decision variables Table A3. Factor loadings and KMO values of GED variables

\section{Abbreviations}

CAPI: Computer-assisted personal interviewing; FPDM: Female participants of decision-making; FVS: Food Variety Score; GEDI: Gender equality in decision-making index; HDDS: Household Dietary Diversity Score; KMO: Kaiser-Meyer-Olkin; PCA: Principal component analysis; PDM: Participants of decision-making; SSA: Sub-Saharan Africa; WPDMI: Women's participation in decision-making index

\section{Acknowledgements}

The authors appreciate the welcoming and open culture of Bhutanese people. We are indebted to Dr. Emily McNulty for proofreading the article, Dr. Ling Yee Khor for helpful comments, and to the anonymous reviewers for their constructive comments.

Authors' contributions

OS and TL had developed the questionnaire that was checked and approved by MZ and TG. OS designed the survey and conducted the interviews together with TG. OS wrote the manuscript, and TL improved its content and language. MZ and TG critically revised the manuscript. All authors read and approved the final manuscript.

\section{Funding}

The research undertaken for this study has been financially supported by the fiat panis Ph.D. Grant from the Foundation fiat panis.

\section{Availability of data and materials}

The datasets generated and/or analyzed during the current study are not publicly available to protect the participant's identities, but are available from the corresponding author on reasonable request.

\section{Ethics approval and consent to participate}

Before conducting the interviews, we obtained the informed consent of all the participants and assured them of confidentiality.

\section{Competing interests}

The authors declare that they have no competing interests.

\section{Author details}

${ }^{1}$ Faculty of Agricultural Science, Hans Ruthenberg Institute, University of Hohenheim, Wollgrasweg 43, 70599 Stuttgart, Germany. ${ }^{2}$ Deutsche Gesellschaft für Internationale Zusammenarbeit (GIZ) GmbH, Bonn, Germany. ${ }^{3}$ College of Natural Resources, Punakha, Bhutan.

Received: 14 May 2019 Accepted: 27 April 2020

Published online: 11 May 2020

\section{References}

Acharya M, Bennett $L$ (1983) Women and the subsistence sector: economic participation and household decision making in Nepal / Meena Acharya, Lynn Bennett. World Bank staff working papers, 0253-2115, no. 526. World Bank, Washington, D. C.

Agarwal B (1994) A field of one's own: Gender and land rights in South Asia / Bina Agarwal. Cambridge University Press, Cambridge, England, New York, Cambridge South Asian studies

Agidew A-mA, Singh KN (2018) Determinants of food insecurity in the rural farm households in South Wollo Zone of Ethiopia: the case of the Teleyayen sub-watershed. Agric Econ 6:1-23. https://doi.org/10.1186/s40100-018-0106-4 
Allendorf K (2007) Do Women's land rights promote empowerment and child health in Nepal? World Development 35:19751988

Asian Development Bank (2014) Bhutan;gender equality diagnostic of selected sectors. O Books Sun \& Moon, Oakland Asian Development Bank (2018) Bhutan: economy. https://www.adb.org/countries/bhutan/economy\#tabs-1-1. Accessed 6 March 2018

Becker S, Fonseca-Becker F, Schenck-Yglesias C (2006) Husbands' and wives' reports of women's decision-making power in Western Guatemala and their effects on preventive health behaviors. Soc Sci Med 62:2313-2326. https://doi.org/10.1016/ j.socscimed.2005.10.006

Bhagowalia P, Menon P, Quisumbing AR, Soundararajan V (2012) What dimensions of women's empowerment matter most for child nutrition? International Food Policy Research Institute (IFPRI). Washington, D.C.

Brauen M (1997) "A village in Central Bhutan" in Christian Schicklgruber and Francoise Pommaret (eds), Bhutan: Mountain Fortress of the Gods (Delhi: Bookwise (India) Pvt Ltd, 1997).

Bundesbank D (2018) Time series databases. Exchange rate statistics (December 2017) https://www.bundesbank.de/resource/ blob/710004/1c115e897653525e26ecbe7495b8dc43/mL/2017-12-exchange-rate-statistics-data.pdf.

Cafiero C, Melgar-Quiñonez HR, Ballard TJ, Kepple AW (2014) Validity and reliability of food security measures. Ann N Y Acad Sci 1331:230-248. https://doi.org/10.1111/nyas.12594

Dorji, L (2003). Sergamathang Kothkin and other Bhutanese Marriage Customs.

Doss C (2014) If women hold up half the sky, how much of the world's food do they produce? In: Quisumbing MAR, Meinzen-Dick RS, Raney TL, Croppenstedt A, Behrman JA, Peterman A (eds) Gender in agriculture: closing the knowledge gap / Agnes R. Quisumbing, Ruth Meinzen-Dick, Terri L.Raney, André Croppenstedt, Julia A. Behrman, Amber Peterman, editors. Springer; [Rome] : Food and Agriculture Organization of the United Nations, Berlin, pp 69-88

Doss C, Meinzen-Dick R, Quisumbing A, Theis S (2018) Women in agriculture: four myths. Glob Food Sec 16:69-74. https:// doi.org/10.1016/j.gfs.2017.10.001

Doss CR, Morris ML (2001) How does gender affect the adoption of agricultural innovations? The case of improved maize technology in Ghana. Agricultural Economics 25:27-39. https://doi.org/10.1016/S0169-5150(00)00096-7

FAO (2000) Fact sheet Bhutan: women in agriculture, environment and rural production.

Fisher M, Carr ER (2015) The influence of gendered roles and responsibilities on the adoption of technologies that mitigate drought risk: the case of drought-tolerant maize seed in eastern Uganda. Global Environmental Change 35:82-92. https://doi.org/10.1016/j.gloenvcha.2015.08.009

Fongar A, Gödecke T, Aseta A, Qaim M (2019) How well do different dietary and nutrition assessment tools match? Insights from rural Kenya. Public Health Nutr 22:391-403. https://doi.org/10.1017/S1368980018002756

Foote JA, Murphy SP, Wilkens LR, Basiotis PP, Carlson A (2004) Dietary variety increases the probability of nutrient adequacy among adults. J Nutr 134:1779-1785. https://doi.org/10.1093/jn/134.7.1779

Garikipati S (2008) The impact of lending to women on household vulnerability and women's empowerment: evidence from India. World Development 36:2620-2642. https://doi.org/10.1016/j.worlddev.2007.11.008

Hashemi SM, Schuler SR, Riley AP (1996) Rural credit programs and women's empowerment in Bangladesh. World Development 24:635-653. https://doi.org/10.1016/0305-750X (95)00159-A

Hatløy A, Torheim LE, Oshaug A (1998) Food variety — a good indicator of nutritional adequacy of the diet? A case study from an urban area in Mali, West Africa. Eur J Clin Nutr 52:891-898

Headey D, Ecker O (2013) Rethinking the measurement of food security: from first principles to best practice. Food Sec. 5: 327-343. https://doi.org/10.1007/s12571-013-0253-0

Henry C, Sharma M, Lapenu C, Zeller M (2003) Microfinance poverty assessment tool. https://openknowledge.worldbank.org/ bitstream/10986/15065/1/275870PAPEROMi1 e0povertyOassessment.pdf

Hoddinott J, Yohannes Y (2002) Dietary diversity as a household food security indicator. Food and Nutrition Technical Assistance Project (FANTA), Academy for Educational Development, 2002.

Kabeer N (2001) Discussing women's empowerment: theory and practice. Sida studies, 1404-9562, no. 3. Swedish International Development Cooperation Agency, Stockholm

Kaiser HF (1960) The application of electronic computers to factor analysis. Educational and psychological measurement 20: $141-151$

Kaiser HF (1974) An index of factorial simplicity. Psychometrika 39:31-36

Kassie M, Stage J, Teklewold H, Erenstein O (2015) Gendered food security in rural Malawi: why is women's food security status lower? Food Sec. 7:1299-1320. https://doi.org/10.1007/s12571-015-0517-y

Kennedy G, Ballard T, Dop MC (2011) Guidelines for measuring household and individual dietary diversity. Food and Agriculture Organization of the United Nations, [Rome]

Koppmair S, Kassie M, Qaim M (2016) Farm production, market access and dietary diversity in Malawi. Public Health Nutr 20: 325-335. https://doi.org/10.1017/S1368980016002135

Magaña-Lemus D, Ishdorj A, Rosson CP, Lara-Álvarez I (2016) Determinants of household food insecurity in Mexico. Agric Econ 4:1-20. https://doi.org/10.1186/s40100-016-0054-9

Malapit HJL, Kadiyala S, Quisumbing AR, Cunningham K, Tyagi P (2015) Women's empowerment mitigates the negative effects of low production diversity on maternal and child nutrition in Nepal. The Journal of Development Studies 51: 1097-1123. https://doi.org/10.1080/00220388.2015.1018904

Malhotra A, Mather M (1997) Do schooling and work empower women in developing countries? Gender and domestic decisions in Sri Lanka. Sociological Forum 12:599-630. https://doi.org/10.1023/A:1022126824127

Malhotra A, Schuler RS (2005) Women's Empowerment as a Variable in International Development: Cross-Disciplinary Perspectives. The World Bank, Washington, D.C.

Miller BD (1997) Social class, gender and intrahousehold food allocations to children in South Asia. Social Science \& Medicine 44:1685-1695. https://doi.org/10.1016/S0277-9536(96)00371-1

Minten B, Dukpa C (2015) Technology adoption, agricultural productivity, and road infrastructure in Bhutan

Mukherjee A (ed) (2009) Eight food insecurities faced by women and girl children: four steps that could make a difference, with special reference to South Asia 
Ndiritu SW, Kassie M, Shiferaw B (2014) Are there systematic gender differences in the adoption of sustainable agricultural intensification practices? Evidence from Kenya. Food Policy 49. Part 1:117-127. https:/doi.org/10.1016/j.foodpol.2014.06.010

Neuhoff D, Tashi S, Rahmann G, Denich M (2014) Organic agriculture in Bhutan: potential and challenges. Organic Agriculture 4:209-221. https://doi.org/10.1007/s13165-014-0075-1

Nilsson M (2017) Important interactions among the sustainable development goals under review at the high-level political forum 2017. SEl, Stockholm

Pain A, Pema D (2004) The matrilineal inheritance of land in Bhutan. Contemporary South Asia 13:421-435. https://doi.org/10 1080/09584930500070654

Ragasa C (2012) Gender and institutional dimensions of agricultural technology adoption: a review of literature and synthesis of 35 case studies:56

Ruel MT (2003) Operationalizing dietary diversity: a review of measurement issues and research priorities. J Nutr 133:3911S3926S. https://doi.org/10.1093/jn/133.11.3911S

Sariyev O, Loos, TK, Zeller M (2020). Women's participation in decision-making and its implications for human capital investment. European Review of Agricultural Economics, Article jbaa008. Advance online publication. https://doi.org/10 1093/erae

Schmidt EM (2012) The effect of women's intrahousehold bargaining power on child health outcomes in Bangladesh. Undergraduate Economic Review 9:4

Schuler SR, Hashemi SM, Cullum A, Hassan M (1996) The advent of family planning as a social norm in Bangladesh: women's experiences. Reproductive Health Matters 4:66-78. https://doi.org/10.1016/S0968-8080(96)90007-5

Schutter O (2013) Gender equality and food security: women's empowerment as a tool against hunger. Asian Development Bank, Mandaluyong City Metro Manila Philippines.

Shakespear L (2012) History of Upper Assam. Cambridge University Press, Upper Burmah and North-Eastern Frontier

Sibhatu KT, Qaim M (2018) Review: Meta-analysis of the association between production diversity, diets, and nutrition in smallholder farm households. Food Policy 77:1-18. https://doi.org/10.1016/j.foodpol.2018.04.013

Simtowe F, Asfaw S, Abate T (2016) Determinants of agricultural technology adoption under partial population awareness: the case of pigeonpea in Malawi. Agric Econ 4:1-21. https://doi.org/10.1186/s40100-016-0051-z

Sraboni E, Malapit HJ, Quisumbing AR, Ahmed AU (2014) Women's empowerment in agriculture: what role for food security in Bangladesh? World Development 61:11-52. https://doi.org/10.1016/j.worlddev.2014.03.025

Steyn NP, Nel JH, Nantel G, Kennedy G, Labadarios D (2006) Food variety and dietary diversity scores in children: are they good indicators of dietary adequacy? Public Health Nutr 9:644-650

Tahirih Justice Center (2014) Tahirih - Forced marriage initiative forced marriage overseas: Bhutan. http:// preventforcedmarriage.org/forced-marriage-overseas-bhutan/. Accessed 16 March 2018

ThingsAsian (2002) Bhutan bucks regional trend in attitude to women / ThingsAsian. http://thingsasian.com/story/bhutanbucks-regional-trend-attitude-women. Accessed 6 March 2018

Tibesigwa B, Visser M (2016) Assessing gender inequality in food security among small-holder farm households in urban and rural South Africa. World Development 88:33-49. https://doi.org/10.1016/j.worlddev.2016.07.008

UNICEF (2013) Statistics - Bhutan. https://www.unicef.org/infobycountry/bhutan_statistics.html. Accessed 16 March 2018

United Nations Development Program (2018) Human development reports. http://hdr.undp.org/en/composite/Gll. Accessed 8 March 2018

Wilcoxon F (1945) Individual comparisons by ranking methods. Biometrics bulletin 1:80-83

World Bank (2013) Bhutan gender policy note. https://openknowledge.worldbank.org/bitstream/10986/16737/1/ACS4551 OPNTOP10Box0379884B00PUBLICO.pdf

World Health Organization (2018) UN Sustainable Development Summit 2015. http://www.who.int/mediacentre/events/ meetings/2015/un-sustainable-development-summit/en/. Accessed 5 March 2018

\section{Publisher's Note}

Springer Nature remains neutral with regard to jurisdictional claims in published maps and institutional affiliations.

\section{Submit your manuscript to a SpringerOpen ${ }^{\circ}$ journal and benefit from:}

- Convenient online submission

- Rigorous peer review

- Open access: articles freely available online

- High visibility within the field

- Retaining the copyright to your article

Submit your next manuscript at $\boldsymbol{s p r i n g e r o p e n . c o m ~}$ 